\title{
XPS and NEXAFS Analysis of Dimethyl Sulfide Adsorbed on the Rh(PVP) Nanoparticle Surface
}

\author{
Hironori Niwa Non-member (Nagoya University, niwa.hironori@a.mbox.nagoya-u.ac.jp) \\ Satoshi Ogawa Non-member (Nagoya University, ogawa.satoshi@g.mbox.nagoya-u.ac.jp) \\ Galif Kutluk Non-member (Hiroshima University, gkutluk@hiroshima-u.ac.jp) \\ Shinya Yagi Non-member (Nagoya University, s-yagi@nucl.nagoya-u.ac.jp)
}

Keywords : Rh, X-ray photoelectron spectroscopy, near edge X-ray absorption fine structure, dimethyl sulfide, nanoparticle

The nanoparticles of platinum-group metals ( $\mathrm{Rh}, \mathrm{Pd}$ and $\mathrm{Pt}$ ) are used as the purification catalyst for the toxic substances like as $\mathrm{NO}_{\mathrm{X}}, \mathrm{HC}$ and $\mathrm{CO}$ in the exhaust gas. However, there is a problem of the deterioration of the catalytic performance, known as sulfur poisoning, caused by adsorbing of the sulfur-containing molecule in the automobile fuel on the surface of catalyst. The purpose of this study is to reveal the adsorption reaction of dimethyl sulfide (DMS: $\left.\left(\mathrm{CH}_{3}\right)_{2} \mathrm{~S}\right)$ on the $\mathrm{Rh}(\mathrm{PVP})$ nanoparticles by using atomic force microscopy (AFM), X-ray photoelectron spectroscopy (XPS) and near edge X-ray absorption fine structure (NEXAFS) techniques.

We prepared the Rh(PVP) nanoparticles by chemical reduction method. In order to investigate the difference in the adsorption reaction depending on the amount of the $\mathrm{Rh}(\mathrm{PVP})$ nanoparticle, three kinds of samples were prepared by spin-coating method on Ni substrates and heated up to $723 \mathrm{~K}$ in the air; sample (A) was put double drops of $200 \mu \mathrm{l}$ h(PVP) nanoparticles colloidal solution, sample (B) was done single drop, and sample (C) was done double drops of $200 \mu \mathrm{l}$ PVP solution without $\mathrm{Rh}$ nanoparticles. Subsequently, they were exposed to DMS under a constant pressure of $1.0 \times 10^{-8}$ Torr for $20 \mathrm{sec}(0.2 \mathrm{~L})$ after cooling down to $90 \mathrm{~K}$.

The diameters of nanoparticles were evaluated by AFM measurement for the height values of them. The XPS measurement was carried out at $90 \mathrm{~K}$ and room temperature before
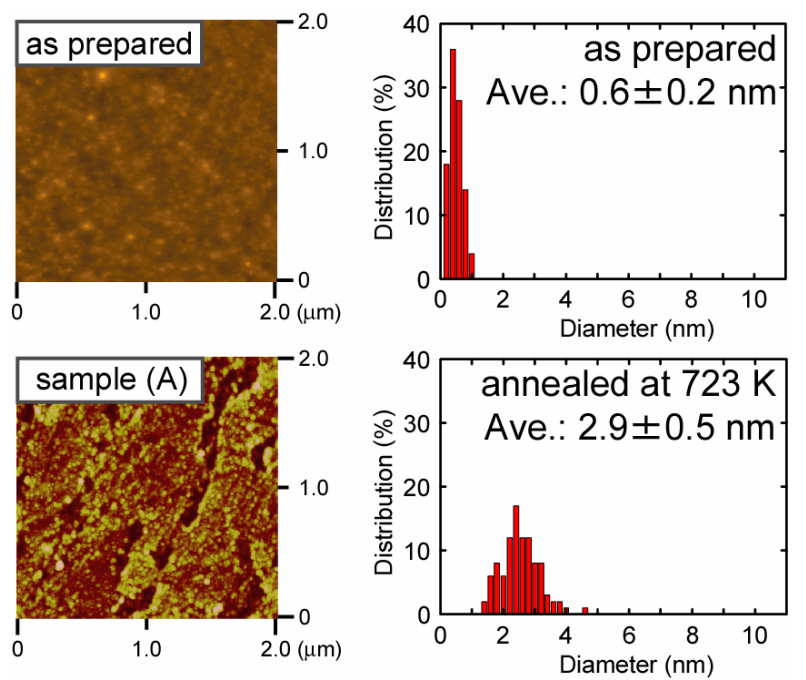

Fig. 1. AFM images and diameter distributions of $\mathrm{Rh}(\mathrm{PVP})$ nanoparticles as prepared and annealed at 723 $\mathrm{K}$ (sample (A)). exposing to the air (in-situ XPS) and at room temperature after exposing to the air (ex-situ XPS). The NEXAFS measurement was carried out with He-path system at BL-3 on Hiroshima Synchrotron Radiation Center (HSRC).

Fig. 1 shows AFM images and diameter distributions of $\mathrm{Rh}$ (PVP) nanoparticles. The estimated average diameters and standard deviations are $0.6 \pm 0.2$ and $2.9 \pm 0.5 \mathrm{~nm}$, respectively corresponding to the samples of as prepared and annealed at 723 $\mathrm{K}$ (samples (A)). The particle diameter of annealed at $723 \mathrm{~K}$ is bigger than that of as prepared sample. It is considered that each $\mathrm{Rh}(\mathrm{PVP})$ nanoparticle is aggregated by annealing.

Fig. 2 shows S 2p in-situ XPS spectra for samples (A) and (C) at $90 \mathrm{~K}$ and RT. These spectra have been deconvoluted into three components, which are DMS, methanethiolate (MT: $\left.\mathrm{CH}_{3} \mathrm{~S}-\right)$ and atomic $\mathrm{S}$. The spectra at $90 \mathrm{~K}$ show that the peak intensities of DMS for sample (A) are smaller than that for sample (C). It is considered that the $\mathrm{Rh}(\mathrm{PVP})$ nanoparticles are contributing to DMS dissociation at $90 \mathrm{~K}$. Compared the spectra at RT with them at $90 \mathrm{~K}$, the peak intensity of the component for the atomic $\mathrm{S}$ is the largest for both samples at RT. It is thought that the DMS dissociation into atomic $\mathrm{S}$ does not depend upon the existence of the Rh(PVP) nanoparticles at RT. This result about sample (C) means that the PVP without the Rh nanoparticle possesses the ability to dissociate the DMS into atomic S at RT.

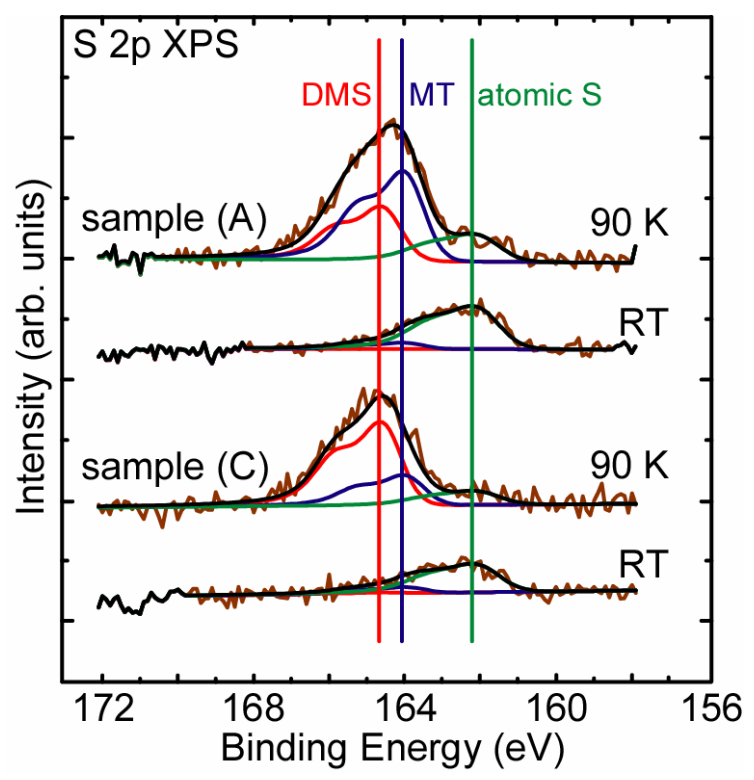

Fig. 2. $\quad$ S $2 p$ in-situ XPS spectra for samples (A) and (C) at $90 \mathrm{~K}$ and $\mathrm{RT}$. 


\title{
$\mathrm{Rh}(\mathrm{PVP})$ ナノ粒子表面に吸着した硫化ジメチルの XPS およびNEXAFS 解析
}

\author{
非会員 丹羽 悠登* 非会員 小川 智史* \\ 非会員 Galif Kutluk** 非会員 八木 伸也*
}

\begin{abstract}
XPS and NEXAFS Analysis of
Dimethyl Sulfide Adsorbed on the Rh(PVP) Nanoparticle Surface

Hironori Niwa*, Non-member, Satoshi Ogawa*, Non-member, Galif Kutluk**, Non-member, Shinya Yagi*, Non-member
\end{abstract}

We have studied the adsorption reaction of dimethyl sulfide (DMS: $\left.\left(\mathrm{CH}_{3}\right)_{2} \mathrm{~S}\right)$ on the surface of $\mathrm{Rh}(\mathrm{PVP})$ nanoparticles by using AFM, XPS and NEXAFS techniques. The AFM images show the degree of dispersion of the Rh(PVP) nanoparticles depends on the amount of them. The in-situ XPS results indicate that the dissociation reaction of DMS into atomic $\mathrm{S}$ does not depend upon the existence of the Rh(PVP) nanoparticles. The NEXAFS results show that there is a strong chemical bonding between Rh(PVP) nanoparticle and atomic S. The ex-situ XPS results show the atomic S adsorbed on the Rh(PVP) nanoparticles partially desorb by exposing to the air.

キーワード : Rh, X 線光電子分光法 (XPS), 吸収端近傍 X 線微細構造法 (NEXAFS), 硫化ジメチル (DMS), ナノ粒子

Keywords : Rh, X-ray photoelectron spectroscopy, near edge X-ray absorption fine structure, dimethyl sulfide, nanoparticle

\section{1. まえがき}

現在自動車排気ガスは大気污染の原因の一つとなってお り，酸性雨などの深刻な環境問題を引き起こしている。環 境への負荷を低減するため, 排気ガス中の有害物質である $\mathrm{NO}_{\mathrm{X}}, \mathrm{HC}, \mathrm{CO}$ を無害化する性能を持つ白金族元素 $(\mathrm{Rh}$, $\mathrm{Pd} ， \mathrm{Pt})$ が自動車排気ガス浄化触媒として実用化されてい る。またこの浄化反応は触媒表面で起こるため, 触媒金属 をナノ粒子化して比表面積を増すことにより浄化効率を向 上することが可能である。しかしながらガソリン然料中に 含まれる硫黄を含む分子 (以降, 含硫黄分子) が触媒表面に 吸着・残留すると, 浄化すべき有害物質の触媒表面への吸 着を妨げ，結果触媒性能の低下を引き起こす「硫黄被毒」 という問題が生じる ${ }^{(1)}$ 。希少かつ高価な白金族元素の使用量 節減のためには，この硫黄被毒の原因である含硫黄分子の 吸着・解離反応を解明する必要がある。これまでの研究に よれば，Rh は白金族元素の中でも最も硫黄被毒に対する耐

\footnotetext{
* 名古屋大学 工学研究科 量子工学専攻

干464-8603 愛知県名古屋市千種区不老町

Department of Quantum Engineering, School of Engineering,

Nagoya University

Hurocho, Chikusa-ku, Nagoya, Aichi 464-8603

** 広島大学放射光科学研究センター

干739-0046 広島県東広島市鏡山 2-313

Hiroshima Synchrotron Radiation Center, Hiroshima University

2-313, Kagamiyama, Higashihiroshima, Hiroshima 739-0046
}

性や回復能力が優れており, 長寿命な触媒として期待され ている(2)。そのため本研究では, この優れた特性を持つ Rh に注目した。

本研究では, 低価格で大量生産が可能であり自動車排気 ガス浄化触媒の作製にも実用化されている溶液還元法で Rh ナノ粒子の作製を行った。この手法では Rhのイオンをエタ ノールと水の混合液中で還元してナノ粒子を形成し, 分散 剂として添加したポリビニルピロリドン (PVP) によって それぞれのナノ粒子同士の凝集を防ぐことにより作製が可 能である(3)(4)。これまでにPVP を分散剤として使用する金属 ナノ粒子の合成手法は数多く研究されており, ナノ粒子の 粒径の制御について報告されている(5) (7)。しかしPVPを用 いることにより, PVP が Rhナノ粒子の表面に残留しその表 面の化学状態に影響を及ぼすことが考えられる ${ }^{(8)}$ 。その表面 の硫黄被毒への影響を明らかにするためには, Rh(PVP) ナ ノ粒子表面への含硫黄分子の吸着反応について調べる必要 がある。

これまでの研究で, 我々は $\mathrm{Rh}(100)$ 単結晶表面への硫化 ジメチル (DMS: $\left.\left(\mathrm{CH}_{3}\right)_{2} \mathrm{~S}\right)$ の吸着反応を明らかにした ${ }^{(2)}$ 。研 究結果から, Rh 表面に多くのステップエッジ構造が存在す るほど DMS の原子状硫黄 (atomic S) への解離反応に対す る活性が増大することがわかった。ナノ粒子の表面は単結 晶に比べ多くのステップエッジ構造を持つため, Rh(PVP) 
ナノ粒子はRh 単結晶よりも高い活性を持つことが予想され る。また $\mathrm{Rh}(100)$ 表面に硫黄原子を吸着した試料を酸素雰 囲気中で加熱すると吸着した硫黄が脱離し，硫黄により被 毒された状態から回復することが報告されている(9)。この脱 離は吸着した硫黄が酸化することにより Rh との結合が弱ま った結果生じたものであるため，大気中にさらして酸化を 促すことによっても同様に硫黄の脱離が起こると考えられ る。本研究の目的は, 原子間力顕微鏡 $(\mathrm{AFM}), \mathrm{X}$ 線光電子 分光法 (XPS), 吸収端近傍 X 線吸収微細構造法 (NEXAFS) を用いて Rh(PVP) ナノ粒子表面への DMS の吸着反応を明 らかにすることである。

\section{2. $\mathrm{Rh}(\mathrm{PVP})$ ナノ粒子とその表面への DMS 吸着 試料の作製および実験手法}

$\mathrm{Rh}(\mathrm{PVP})$ ナノ粒子の作製は溶液還元法により行った ${ }^{(10)}$ 。 PVP はキシダ化学から購入した平均分子量 10,000 (K-15) の ものを使用した。 Rh(PVP) ナノ粒子のコロイド溶液を $\mathrm{Ni}$ 基 板 $\left(10 \times 10 \mathrm{~mm}^{2}, 0.50 \mathrm{~mm}\right.$ 厚 $)$ 上に滴下し，4,000 rpm でスピ ンコーティングした後に大気中 $723 \mathrm{~K}$ で加熱した。Rh(PVP) ナノ粒子の量に依存した吸着反応の違いを明らかにするた め, $\mathrm{Rh}(\mathrm{PVP})$ ナノ粒子のコロイド溶液 $200 \mu \mathrm{l}$ を 2 回滴下し た sample (A), 1 回滴下した sample (B), Rh ナノ粒子を含ま ない PVP の溶液 $200 \mu \mathrm{l}$ を 2 回滴下した sample $(\mathrm{C})$ の 3 種類 の試料を作製した。

作製したそれぞれの試料の $\mathrm{Rh}(\mathrm{PVP})$ ナノ粒子の表面に は, 大気中 $723 \mathrm{~K}$ での加熱後にも不純物が残留している ${ }^{(11)}$ 。 Rh(PVP) ナノ粒子の表面に存在する PVP の然えかすや大気 由来の不純物を取り除くため, $\mathrm{Ar}^{+}$スパッタリング $(3 \mathrm{keV}$, 90 分) により sample (A), (B)表面の清浄化を行った。 $\mathrm{Rh}(\mathrm{PVP})$ ナノ粒子表面の清浄化は XPS 測定 (Rh 3d, S 2p, O 1s，N 1s，C 1s) により評価した。 sample (C)は sample (A), (B)と同じ時間 $\mathrm{Ar}^{+}$スパッタリングを行った。表面を清浄化 した 3 種類の試料を $90 \mathrm{~K}$ に冷却した後, DMS 分子のガスを $1.3 \times 10^{-6} \mathrm{~Pa}$ で 20 秒間曝露した $(0.2 \mathrm{~L})$ 。

作製した粒子の粒径は，AFM 測定により得られた粒子の 高さ方向の值を用いて見積もった。AFM 測定はVeeco 社製 の Nanoscope III-a を用いてタッピングモードにより行った。 XPS 測定は MgKa線 $(1253.6 \mathrm{eV})$ および SPECS の半球型ア ナライザー (PHOIBOS100-5ch) を用いて, DMS を曝露・吸 着した in-situ 条件では $90 \mathrm{~K}$ と室温において行い, 大気曝露 した ex-situ 条件では室温において行った。NEXAFS 測定は 広島大学放射光科学研究センターの軟 X 線二結晶分光ビー ムライン BL-3 にて, $\mathrm{He}$ パスシステムを用いて ex-situ 条件 で行った ${ }^{(12)(13)}$ 。試料から放出される蛍光 $\mathrm{X}$ 線の検出には $\mathrm{P}-10$ ガス $\left(\mathrm{CH}_{4} 10 \mathrm{~V} \%\right.$ in $\left.\mathrm{Ar}\right)$ によって満たした蛍光比例計 数管を用いた。

\section{3. 実験結果}

〈3·1〉 AFM 測定結果 図 1 に Rh(PVP) ナノ粒子の AFM 画像と粒径分布を示寸。 sample (A), (B)の AFM 画像に
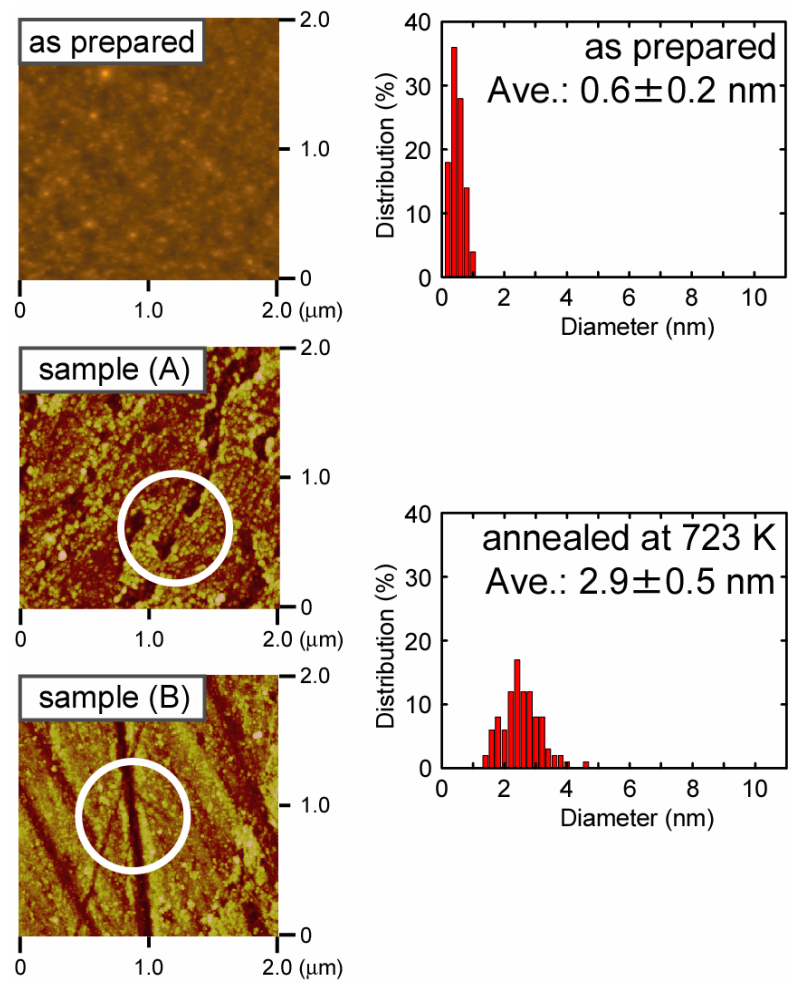

Fig. 1. AFM images and diameter distributions of Rh(PVP) nanoparticles as prepared and annealed at $723 \mathrm{~K}$ (samples (A) and (B)).

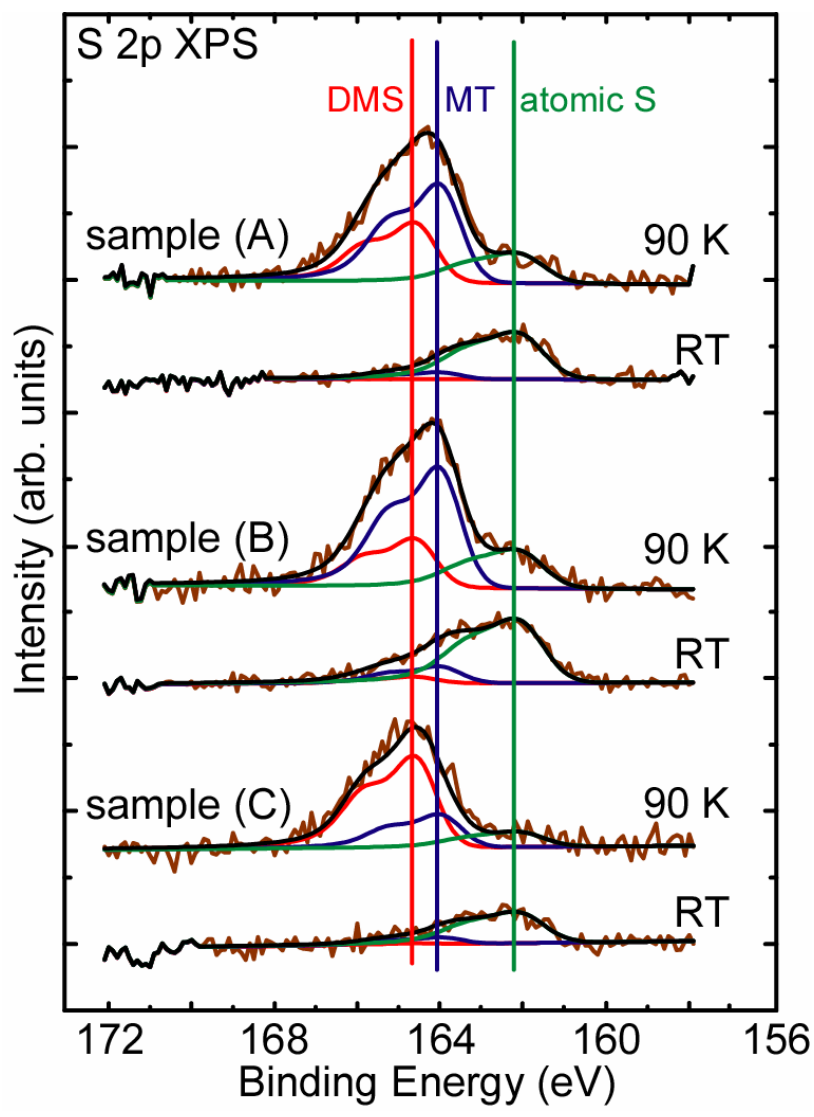

Fig. 2. S 2p in-situ XPS spectra for samples (A), (B) and (C) at $90 \mathrm{~K}$ and RT. 
白円で囲んだ部分に見られる溝は， Ni 基板表面を $0.05 \mu \mathrm{m}$ の $\mathrm{Al}_{2} \mathrm{O}_{3}$ で研磨した際に形成したものだと考えられる。見積 もった平均粒径と標準偏差はアニール前の試料が $0.6 \pm 0.2$ $\mathrm{nm}$, アニール後の試料 (sample (A), (B)) が $2.9 \pm 0.5 \mathrm{~nm}$ であ つた ${ }^{(10)}$ 。それぞれの粒径を比較すると，アニール後の試料 ではアニール前の試料より粒径が大きくなっている。この ことから，アニールにより Rh(PVP) ナノ粒子同士の凝集が 起こったと判断できる。次に sample (A)と(B)の AFM 画像を 比較すると, sample (A)では白円で示した部分の基板の溝が 埋まっているのに対して, sample (B)では基板の溝が深く残 っている。さらに, sample (A)の粒子は sample (B)のものに 比べより凝集していることがわかる。この sample (A)と(B) 表面の粒子の分散性の違いは，DMS 吸着反応において差を 生じる可能性がある。この吸着反応の違いについては後述 する in-situ XPS の測定結果についての議論の中で明らかに する。

$\langle 3 \cdot 2\rangle$ in-situ XPS 測定結果 図 2 に sample (A), (B), (C)の in-situ 条件での $90 \mathrm{~K}$ と室温における S 2p XPS スペク トルを示す。これらのスペクトルは DMS, メタンチオレー 卜 (MT: $\mathrm{CH}_{3} \mathrm{~S}-$ ), atomic $\mathrm{S}$ の 3 つの成分にピーク分離した。 $90 \mathrm{~K}$ においてのスペクトルから, sample (A), (B)の DMS の ピーク強度は sample $(\mathrm{C})$ のものより小さいことがわかる。こ れは $90 \mathrm{~K}$ において DMS の解離反応に Rh(PVP) ナノ粒子が 寄与していることを示している。さらに, sample (B)の DMS のピーク強度は sample (A)に比べ小さいことがわかる。これ は $90 \mathrm{~K}$ において sample (B)の方が sample (A)よりも DMS の 解離反応に対する活性が高いことを示している。この XPS 測定結果は AFM 測定の結果と一致するものであり，ナノ粒 子の凝集が活性を低下させていることを示している。次に 室温におけるスペクトルを見ると, 室温では全ての sample のスペクトルにおいて原子状硫黄のピークが最も支配的で あることがわかる。このことから，室温における DMS の原 子状硫黄への解離反応は Rh(PVP) ナノ粒子の有無に依存し ないと考えられる。さらに Ni 上では DMS は解離しないこ とが報告されていることから ${ }^{(14)}$, この sample (C)についての 結果は, 室温において Rh(PVP) ナノ粒子を含まない PVP が DMS の原子状硫黄への解離反応に対する活性を有している ことを示している。

〈3.3〉NEXAFS 測定結果図 3 に sample (A) と(C)の S K-edge NEXAFS スペクトルを示す。また, それぞれの化 学状態における標準試料のスペクトルをあわせて示した。 sample (A)と (C)のスペクトルには原子状硫黄, $\mathrm{DMS}, \mathrm{SO}_{4}{ }^{2-}$ の化学状態に対応する 3 つの特徵的なピークが見られる。 $\mathrm{SO}_{4}{ }^{2-}$-は大気曝露により試料表面に吸着した原子状硫黄が酸 化したものだと考えられる。 sample (A) と (C)のスペクトルを 比較すると, sample (A)の原子状硫黄のピーク強度は sample (C)のものよりも大きい。一方, sample (A)の $\mathrm{SO}_{4}{ }^{2-}$ に起因す るピーク強度は sample $(\mathrm{C})$ のもよりも小さい。これは sample (A)に吸着した原子状硫黄は sample (C)に吸着したも のと比較して $\mathrm{SO}_{4}{ }^{2-}$ の状態まで酸化されにくいことを示して

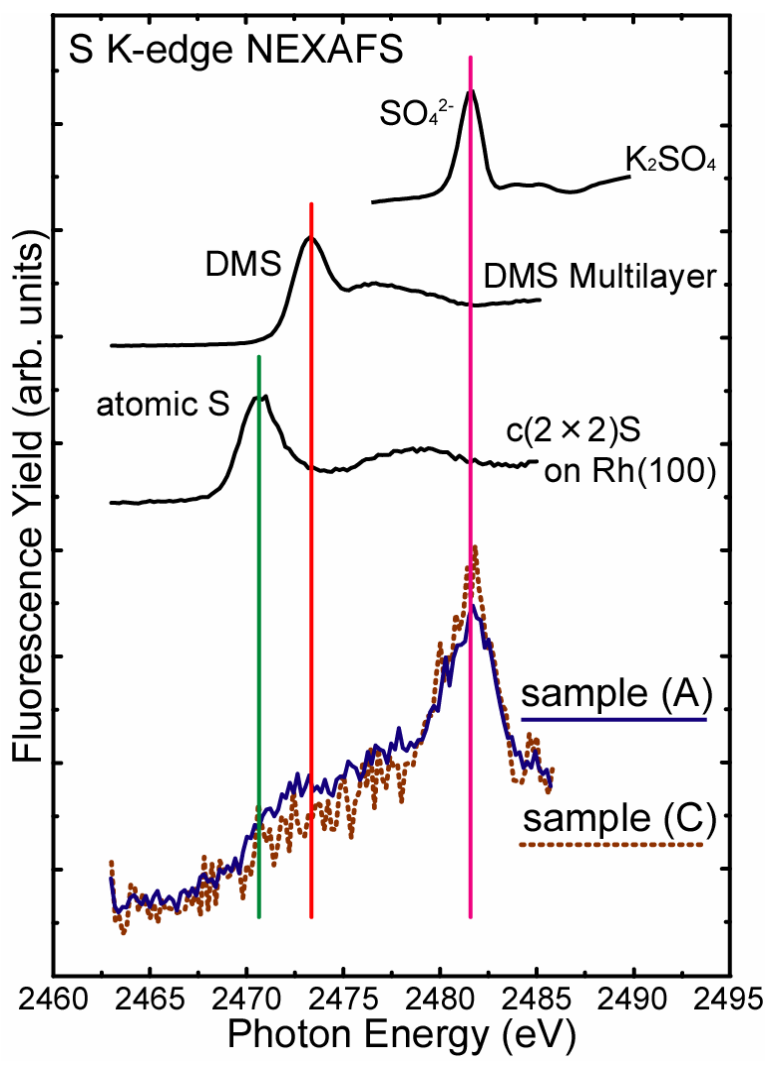

Fig. 3. S K-edge NEXAFS spectra for samples (A), (C), atomic $\mathrm{S}, \mathrm{DMS}$ and $\mathrm{SO}_{4}{ }^{2-}$.

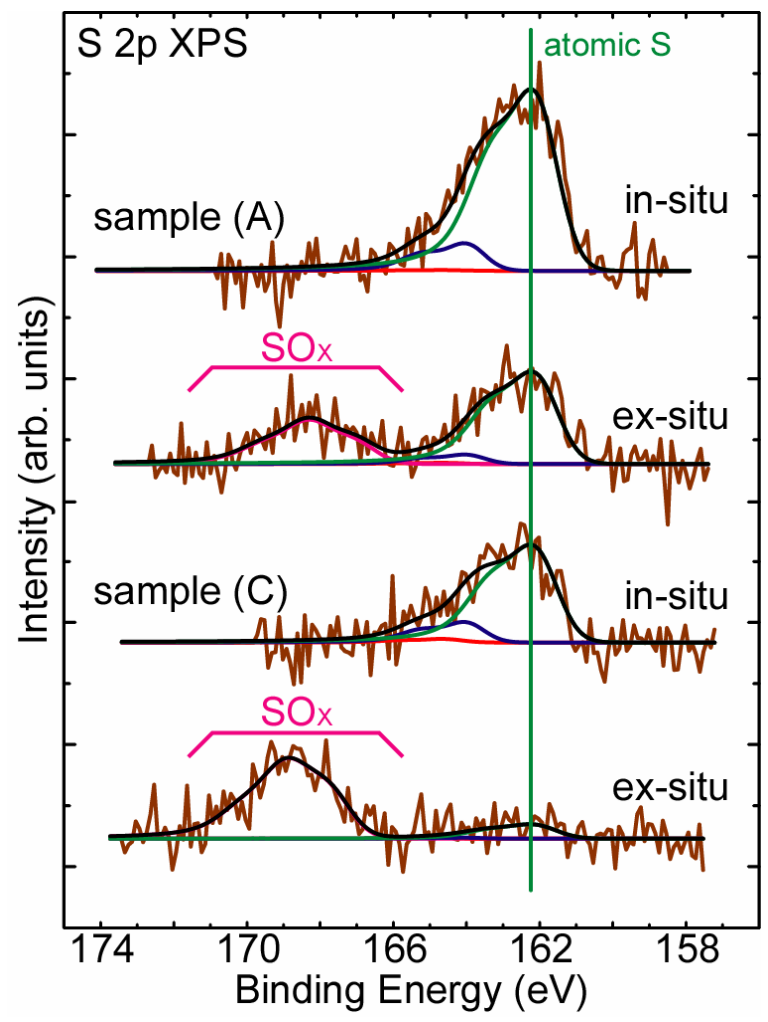

Fig. 4. S 2p ex-situ and in-situ XPS spectra for samples (A) and $(\mathrm{C})$ at RT. 
いる。それゆえ Rh(PVP) ナノ粒子と原子状硫黄の間には強 い化学結合が存在することがわかる。

$\langle 3 \cdot 4\rangle$ ex-situ XPS 測定結果 図 4 に sample (A), (C) の ex-situ 条件での室温における S 2p XPS スペクトルを示 す。大気曝露による吸着種の変化を見るために，図 2 の室 温におけるスペクトルを in-situ としてあわせて示した。大 気曝露によるスペクトルの変化を見ると, sample (A) と sample (C)において atomic S のピークが減少し, その高束縛 エネルギー側 166〜 $171 \mathrm{eV}$ 付近に構造が現れていることがわ かる。次に sample (A) と sample (C)のスペクトルを比較する と, sample (A)では大気曝露後も原子状硫黄のピークが現れ ているのに対して, sample (C)ではほとんど見られず in-situ における原子状硫黄のピーク面積とほぼ同じ面積を持つ構 造が高束縛エネルギー側に現れている。この $166 〜 171 \mathrm{eV}$ 付 近の構造は, sample $(\mathrm{A})$ と sample $(\mathrm{C})$ の表面に吸着した原子 状硫黄を大気中にさらすことで酸化して生成した $\mathrm{SO}_{\mathrm{X}}$ に起 因している(1)。先述した NEXAFS スペクトルでは，この酸 化状態の硫黄は $\mathrm{SO}_{4}{ }^{2-}$ に由来するピークとして他の化学状態 に起因するものより鋭く現れており，吸着種の同定が容易 であった。これはNEXAFS では内殼電子がX 線を吸収して 空準位に励起された後の緩和過程を利用しているため，空 準位が増す酸化状態のピークは強度が増大するという特徵 による。一方 XPS スペクトルにおける高束縛エネルギ一側 の構造の中には他の酸化状態のピークが混在しており, $\mathrm{SO}_{4}^{2-}$-のピークを分離して定量的に扱うのは難しい。そこで 酸化物由来の成分全体を $\mathrm{SO}_{\mathrm{X}}$ として扱い, 吸着種の同定は 行わず吸着量のみに注目して大気曝露によるスペクトル全 体の面積強度の変化を見ると, sample (C)より sample (A)の 方が硫黄の脱離量は多く, sample $(\mathrm{C})$ ではほとんど脱離は起 きていないことがわかった。これらの大気曝露による変化 の違いは, Rhナノ粒子の有無に起因すると考えられる。こ のことから, sample (A)の ex-situ のスペクトルに見られる原 子状硫黄のピークはRhナノ粒子表面に吸着した原子状硫黄 によるものであり， $\mathrm{SO}_{\mathrm{X}}$ のピークは PVP の燃えかすなどに 吸着した原子状硫黄が酸化したことにより現れたと推測で きる。また， Rh ナノ粒子表面に吸着した原子状硫黄は大気 にさらした結果約 3 割が脱離することがわかり, Rh(PVP) ナ ノ粒子は原子状硫黄による被毒から回復していると考えら れる。

\section{4. むすび}

溶液還元法で作製した Rh(PVP) ナノ粒子表面への DMS の吸着・解離反応について明らかにした。作製した Rh(PVP) ナノ粒子の粒径および化学状態は AFM，XPS，NEXAFS を 用いて測定・解析を行った。AFM および in-situ XPS の結果 から，DMS の原子状硫黄への解離反応は $90 \mathrm{~K}$ においては $\mathrm{Rh}(\mathrm{PVP})$ ナノ粒子の分散の度合いによって異なることが明 らかになった。また室温の結果からは分散剤である PVP も また DMS に対する解離活性を有していることがわかり， DMS の原子状硫黄への解離反応は Rh(PVP) ナノ粒子の有
無に依存しないことが明らかとなった。NEXAFS の結果か らは, Rh(PVP) ナノ粒子に吸着した原子状硫黄は PVP に吸 着した場合と比較して $\mathrm{SO}_{4}{ }^{2-}$ の状態まで酸化されにくいこと がわかった。また ex-situ XPS の結果から, Rh(PVP) ナノ粒 子表面に吸着した原子状硫黄の一部は大気にさらすことで 脱離することが示された。

(平成 22 年 2 月 9 日受付, 平成 22 年 5 月 26 日再受付)

\section{文献}

(1) K. Dohmae : "XPS Analysis for Sulfur on Noble Metals", R\&D review of TOYOTA CRDL, Vol.35, No.4, pp.43-50 (2000) (in Japanese) 堂前和彦: 「貴金属表面の硫黄の XPS 解析」, 豊田中央研究所 R\&D レビュー, 35, 4, pp.43-50 (2000)

(2) T. Nomoto, S. Yagi, and K. Soda : "Adsorption behavior of $\left(\mathrm{CH}_{3}\right)_{2} \mathrm{~S}$ on sputtered and annealed $\mathrm{Rh}(100)$ surface by AFM, XPS and NEXAFS", e-J. Surf. Sci. Nanotech., Vol.4, pp.39-45 (2006)

(3) J.-L. Pellegatta, C. Blandy, V. Collière, R. Choukroun, B. Chaudret, P. Cheng, and K. Philippot : "Catalytic investigation of rhodium nanoparticles in hydrogenation of benzene and phenylacetylene", J. Mol. Catal. A, Vol.178, No.1-2, pp.55-61 (2002)

(4) Y. Huang, J. Chen, H. Chen, R. Li, Y. Li, L. Min, and X. Li : "Enantioselective hydrogenation of ethyl pyruvate catalyzed by PVP-stabilized rhodium nanoclusters", J. Mol. Catal. A, Vol.170, No.1-2, pp.143-146 (2001)

(5) W. Weihua, T. Xuelin, C. Kai, and C. Gengyu : "Synthesis and characterization of $\mathrm{Pt}-\mathrm{Cu}$ bimetallic alloy nanoparticles by reverse micelles method", Colloid. Surf. A: Physicochem. Eng. Aspects A, Vol.273, No.1-3, pp.35-42 (2006)

(6) M. M. Koebel, L. C. Jones, and G. A. Somorjai : "Preparation of size-tunable, highly monodisperse PVP-protected Pt-nanoparticles by seed-mediated growth”, J. Nanopart. Res., Vol.10, No.6, pp.1063-1069 (2008)

( 7 ) S. M. Humphrey, M. E. Grass, S. E. Habas, K. Niesz, G. A. Somorjai, and T. D. Tilley : "Rhodium nanoparticles from cluster seeds: Control of size and shape by precursor addition rate", Nano Lett., Vol.7, No.3, pp.785-790 (2007)

(8) M. Kràlik and A. Biffis : "Catalysis by metal nanoparticles supported on functional organic polymers", J. Mol. Catal. A, Vol.177, No.1, pp.113-138 (2001)

(9) T. Nomoto, K. Miura, S. Yagi, G. Kutluk, H. Sumida, K. Soda, E. Hashimoto, H. Namatame, and M. Taniguchi : "Spectroscopic study on thermal reaction and desorption of sulfur $/ \mathrm{Rh}(100)$ induced by oxygen-containing molecules", Surf. Sci., Vol.601, No.18, pp.3784-3787 (2007)

(10) T. Ashida, K. Miura, T. Nomoto, S. Yagi, H. Sumida, G. Kutluk, K. Soda, H. Namatame, and M. Taniguchi : "Synthesis and characterization of Rh(PVP) nanoparticles studied by XPS and NEXAFS", Surf. Sci., Vol.601, No.18, pp.3898-3901 (2007)

(11) T. Ashida : master thesis (Nagoya Univ.) (2007) (in Japanese) 芦田高規：修士論文 (名古屋大学) (2007)

(12) S. Yagi, G. Kutluk, T. Matsui, A. Matano, A. Hiraya, E. Hashimoto, and M. Taniguchi : "Design and performance of a soft X-ray double crystal monochromator at HSRC", Nucl. Instrum. Meth. A, Vol.467-468, No.1, pp.723-726 (2001)

(13) S. Yagi, T. Nomoto, T. Ashida, K. Miura, K. Soda, K. Yamagishi, N. Hosoya, G. Kutluk, H. Namatame, and M. Taniguchi : "XAFS measurement system for nano, bio and catalytic materials in soft X-ray energy region", AIP Conf. Proc., Vol.879, No.1, pp.1638-1641 (2007)

(14) S. Yagi, A. Matano, G. Kutluk, N. Shirota, E. Hashimoto, and M. Taniguchi : "Molecular adsorption of $\left(\mathrm{CH}_{3}\right)_{2} \mathrm{~S}$ on $\mathrm{Ni}(100)$ studied by $\mathrm{S}$ K-edge NEXAFS and XPS", Surf. Sci., Vol.482-485, pp.73-76 (2007) 


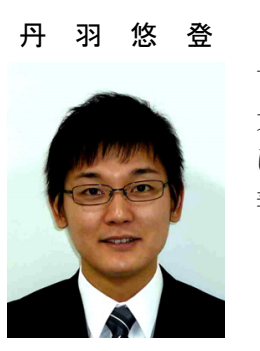

（非会員） 1985 年 3 月 23 日生。 2009 年 3 月名 古屋大学工学部物理工学科卒業。現在, 同大学 大学院工学研究科量子工学専攻博士課程前期 にて修学中。金属ナノ粒子の作製とその硫黄被 毒の実験を行っている。

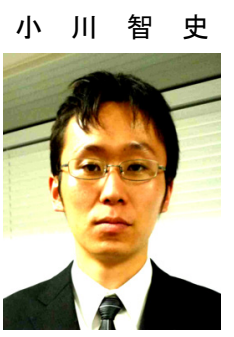

（非会員） 1987 年 2 月 4 日生。 2009 年 3 月名 古屋大学工学部物理工学科卒業。現在, 同大学 大学院工学研究科量子工学専攻博士課程前期 にて修学中。金属ナノ粒子によって構成された 水素吸蔵材料の開発および研究を行っている。

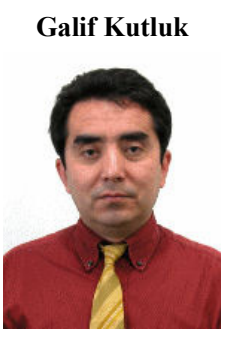

（非会員） 1962 年 4 月 1 日生。1994 年 3 月明 星大学大学院理工学研究科博士 (理学)。文部 省高エネルギー物理学研究所 COE 研究員, 広 島大学放射光科学研究センター研究員。真空治 金（株）（現アルバックマテリアル（株））ナノ パーティクル応用開発部研究員。科学技術振興 機構研究員を経て, 広島大学放射光科学研究セ ンター外国人研究員 (准教授)。金属ナノ粒子 の作製とシンクロトロン放射光を用いたナノ 粒子の電子構造の解析に従事。

八木伸也 (非会員) 1966 年 3 月 23 日生。 1995 年 3 月広 島大学大学院理学研究科修了 (博士 (理学) )。 分子科学研究所 IMS フェロー, 広島大学放射光 科学研究センター助手を経て名古屋大学工学 研究科准教授。金属ナノ粒子の作製とシンクロ トロン放射光を用いた表面・界面の分析に従事。 